\title{
Bacteria in the global atmosphere - Part 1: Review and synthesis of literature data for different ecosystems
}

\author{
S. M. Burrows, W. Elbert, M. G. Lawrence, and U. Pöschl \\ Max Planck Institute for Chemistry, Mainz, Germany \\ Received: 6 March 2009 - Published in Atmos. Chem. Phys. Discuss.: 4 May 2009 \\ Revised: 23 September 2009 - Accepted: 12 October 2009 - Published: 10 December 2009
}

\begin{abstract}
Bacteria are ubiquitous in the atmosphere, with concentrations of bacterial cells typically exceeding $1 \times 10^{4} \mathrm{~m}^{-3}$ over land. Numerous studies have suggested that the presence of bacteria in the atmosphere may impact cloud development, atmospheric chemistry, and microbial biogeography. A sound knowledge of bacterial concentrations and distributions in the atmosphere is needed to evaluate these claims. This review focusses on published measurements of total and culturable bacteria concentrations in the atmospheric aerosol. We discuss emission mechanisms and the impacts of meteorological conditions and measurement techniques on measured bacteria concentrations. Based on the literature reviewed, we suggest representative values and ranges for the mean concentration in the near-surface air of nine natural ecosystems and three human-influenced land types. We discuss the gaps in current knowledge of bacterial concentrations in air, including the lack of reliable, long-term measurements of the total microbial concentrations in many regions and the scarcity of emission flux measurements.
\end{abstract}

\section{Introduction}

Bacteria are one of the many types of biogenic aerosol particles that are ubiquitous in the atmosphere (Jaenicke, 2005; Jaenicke et al., 2007; Elbert et al., 2007). Due to their size, bacteria have a long atmospheric residence time (of the order

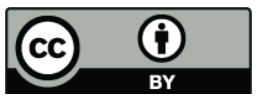

Correspondence to: S. M. Burrows (susannah.burrows@mpic.de) of several days) and can be transported by wind over long distances. Measurements show that mean concentrations in ambient air are likely to be at least $1 \times 10^{4}$ cells $\mathrm{m}^{-3}$ over land (Bauer et al., 2002), while concentrations over sea may be lower than over land by a factor of about 100-1000 (Prospero et al., 2005; Griffin et al., 2006).

The study of airborne microorganisms has a history stretching back hundreds of years, with the earliest mention in 1676 by Antony van Leeuwenhoek (Gregory, 1971). Louis Pasteur was the first to intentionally observe the microbial content of the air, an endeavor that lead to major advances in medicine and disease control, as the spread of many diseases was traced to the aerial dispersal of bacteria (Pasteur, 1860a,b). Today, it is common knowledge that many bacterial diseases are transmitted through the air over short distances. In the case of Legionnaire's disease, there is evidence of airborne transmission up to $6 \mathrm{~km}$ from contaminated industrial cooling towers (Nguyen et al., 2006). Investigators have sampled the microbial populations of the upper air using balloons, airplanes and rockets, and have demonstrated the presence of culturable bacteria at altitudes up to nearly 80 km (Meier, 1935; Rogers and Meier, 1936; Timmons et al., 1966; Imshenetsky et al., 1978). Until recently, however, most measurements of bacteria in the air were sporadic, qualitative and exploratory, and few attempts were made at systematic or quantitative studies. For more on the early history of aerobiology, see Gregory $(1971,1973)$ and Lidwell (1987).

Modern developments in the fields of microbiology and meteorology have opened up new possibilities for the study of bacteria and other biological particles in the air. At

Published by Copernicus Publications on behalf of the European Geosciences Union. 
present, however, aerobiology is a field still characterized by a remarkable lack of knowledge and an abundance of speculation. Few observations have been published, and the lack of a standard, modern methodology makes the interpretation and intercomparison of results difficult. Much of the speculation has focussed on potential interactions between atmospheric bacteria and the Earth's biogeochemical systems. It has been suggested that the presence of bacteria in the air could impact cloud formation by acting as ice nuclei and cloud condensation nuclei and development, with implications for the global distribution of clouds and precipitation, and for climate (Schnell and Vali, 1972, 1973; Yankofsky et al., 1981a,b; Levin and Yankofsky, 1988; Caristi et al., 1991; Sands et al., 1992; Bauer et al., 2003; Diehl et al., 2006; Morris et al., 2005; Sun and Ariya, 2006; Möhler et al., 2007; Christner et al., 2008; Junge and Swanson, 2008; Möhler et al., 2008; Mortazavi et al., 2008; Ariya et al., 2009; Pratt et al., 2009; Prenni et al., 2009). Since bacteria have also been shown to metabolize within cloud droplets, some authors have proposed an impact on the chemistry of cloud droplets and air (Ariya et al., 2002; Amato et al., 2005, 2007a,b; Deguillaume et al., 2008). Finally, the transport of bacteria through the air is relevant to the field of microbial biogeography, the study of the geographic distribution of microbial taxa (Martiny et al., 2006). The dispersal through the air is a pathway for rapid long-distance dispersal of microbes (including bacteria and microscopic eukaryotes), allowing some species to overcome geographic barriers. The efficiency and randomness of airborne dispersal is an important factor in determining whether evolutionary history and chance events play a role in the distribution of taxa (Finlay, 2002; Pringle et al., 2005).

Bacteria enter the atmosphere as aerosol particles from practically all surfaces, including soil, water, and plant surfaces (Jones and Harrison, 2004). Once in the air, they are carried upwards by air currents and may remain in the atmosphere for many days before being removed by precipitation or direct deposition onto surfaces. Studies focussing on the transport of bacteria have mainly considered mesoscale dispersal (Knudsen, 1989) or the implications for the spread of disease (e.g., Gloster et al., 1981, 1982; Donaldson et al., 1982; Addiss et al., 1989; Sørensen et al., 2000), although a very general discussion of the topic was published by Wolfenbarger (1946). Studies of long-range transport have focussed on case studies (Bovallius et al., 1978a) or intermittent events (Prospero et al., 2005). However, there is no reason to assume a priori that longer-range transport is limited to isolated events. Indeed, most bacteria fall into the size range of particles with the longest atmospheric residence times, so their transport over long distances should be an ordinary occurrence, if perhaps intermittent, as it is for dust particles of this size range.

The concentrations of airborne culturable bacteria were measured as early as 1883 by Miquel, and since then, many others have conducted measurements in a variety of locations. These measurements have shown that the concentration of bacteria in air can vary over orders of magnitude during the course of a day at a single location, and that long-term mean concentrations vary according to season and measurement location. Near-surface concentration measurements have been previously reviewed by several authors with respect to specific problems (long-range transport: Bovallius et al., 1980; annual and diurnal variability: Lighthart, 1997; increases in bacterial concentration during dust storms: Kellogg and Griffin, 2006; emission mechanisms and the effect of meteorological variables: Jones and Harrison, 2004).

Microorganisms in aqueous and terrestrial environments are known to play an important role in biogeochemical cycles, both by fixing atoms into organic matter and by biodegradation of organic compounds. It has been proposed that biodegradation may also play a role in the chemistry of organic compounds in the troposphere (Herlihy et al., 1987; Ariya et al., 2002; Ariya and Amyot, 2004). One necessary condition is that the bacteria found in cloud water must be capable of metabolism with the nutrients available in cloud droplets, at ambient cloud temperatures. It is now clear that these bacteria are not only capable of metabolism under these conditions, but also of growth and reproduction. Bacteria collected in cloud water samples have been shown to metabolize and reproduce when those samples are incubated in the laboratory, even at supercooled temperatures (Sattler et al., 2001; Amato et al., 2007a). Sattler et al. (2001) found that generation times varied between 3.6 and 19.5 days, comparable to those of phytoplankton in the ocean. The mean atmospheric residence time of a bacterial cell can be up to about one week, as discussed in a companion paper (Burrows et al., 2009), but the cell will spend only a small fraction of this time inside of a cloud droplet (Lelieveld and Heintzenberg, 1992 estimated that on average, tropospheric air spends about $5 \%$ to $6 \%$ of its time in clouds). It is thus unlikely that there is a significant primary production of bacteria within cloud droplets.

A sound knowledge of the concentration and distribution patterns of airborne bacteria on a global scale is needed in order to assess their importance for the climate and health effects of atmospheric aerosol (Pöschl, 2005), including cloud formation and development, microbial biodiversity, and atmospheric chemistry. This literature review lays a foundation for future investigation of this topic by summarizing a broad collection of published measurements of bacteria concentrations in the ambient air and estimated fluxes of bacteria to the atmosphere (Table S2 and Table S3, see http://www.atmos-chem-phys.net/9/9263/2009/ acp-9-9263-2009-supplement.pdf). Although bacterial ice nucleation is an important motivation for studying this topic, this review deals with observations of the total bacteria in the atmosphere, as opposed to the ice-nucleation-active component. Measurement issues that affect the interpretation of these results are discussed in Sect. 2. Mechanisms of emission to the atmosphere are outlined in Sect. 3. An overview 
of the reviewed data is given in Sect. 4. Airplane measurements, which give insight into the role of vertical transport in atmospheric dispersal, are discussed in Sect. 5. The size distribution of bacteria in the atmosphere is discussed in Sect. 6, while the effect of climatological variables is discussed in Sect. 7. Particular attention is paid to the effect of land use or ecosystem type on observed concentrations (Sect. 8), as a step towards developing an emissions parameterization for use in atmospheric models. A companion paper, (Burrows et al., 2009), presents estimates for the rate at which bacteria enter the atmosphere from ten different ecosystem classes.

\section{Measurement issues}

Studies characterizing bacterial aerosol use a combination of techniques from aerosol science and microbiology, requiring an interdisciplinary approach. A variety of methods exist for measuring and analyzing bacteria in the atmosphere, which are largely incompatible with each other, as will be explained below. Although new methods promise to help resolve many measurement issues, until very recently most published measurements were made using older techniques, particularly culture-based methods, which present serious methodological difficulties.

\subsection{Aerosol sampling issues}

The instrumentation used for aerosol sampling can introduce several types of errors and biases, due mainly to wall losses on tubes and inlets (Hinds, 1999). The use of filtration vs. impaction as a collection method has been discussed by Kel$\operatorname{logg}$ and Griffin (2006). Finally, special care must be taken to avoid microbiological contamination of the sample or the sampling equipment (for instance, the introduction of bacteria during the transport of samples). The effectiveness of anti-contamination measures can be tested by use of a blind control.

\subsection{The problem of culturability}

Historically, most authors have measured the concentrations of airborne culturable bacteria (sometimes misleadingly referred to as "viable" bacteria, see Table S1, see http://www.atmos-chem-phys.net/9/9263/2009/ acp-9-9263-2009-supplement.pdf) by collecting particulate matter via impaction on a culture medium and subsequently counting the colonies formed. However, the vast majority of environmental bacteria are non-culturable, even when viable (Staley and Konopka, 1985; Roszak and Colwell, 1987; Amann et al., 1995; Colwell, 2000; Wainwright et al., 2004). This may be particularly true of bacteria in the air, since the culturability of bacteria rapidly decreases following aerosolization (Heidelberg et al., 1997). The sampling efficiency and culturability of viable bacteria depend strongly on the bacterial strain, but also on experimental and environmental factors, including the growth medium used (ZoBell and Mathews, 1936; Kelly and Pady, 1954; Shahamat et al., 1997; Griffin et al., 2006), the choice of impaction vs. filtration as a collection method (Stewart et al., 1995), the incubation temperature and length of incubation time (Wang et al., 2007, 2008), the air sample volume (Griffin et al., 2006), and the relative humidity (Tong and Lighthart, 1999; Wang et al., 2001). The fraction of airborne bacteria that are detected by culture methods is typically less than $10 \%$, with an observed range of $0.01 \%$ to $75 \%$, and average values estimated at about 1\% (Lighthart, 2000; Chi, 2007; Heidelberg et al., 1997). Additionally, fungal growth on agar plates may interfere with counting of bacterial colonies, and the use of selective media could introduce additional biases.

The problem of culturability should be taken seriously by future studies, since the dependence of culturability on environmental conditions introduces uncontrolled and unknown systematic errors into experiments. For example, in a study of bacteria in cloud water, Amato et al. (2007c) found that the highest total bacterial concentrations were obtained in winter, while the highest culturable bacterial concentrations were obtained in summer. In addition, the culturability at both $15^{\circ} \mathrm{C}$ and at $27^{\circ} \mathrm{C}$ showed a seasonal dependence, with higher culturability at $15^{\circ} \mathrm{C}$ during winter and spring, and higher culturability at $27^{\circ} \mathrm{C}$ during summer and autumn. This effect could be the result of a selection mechanism or a bacterial response to environmental conditions. Whatever the cause, this study demonstrated a systematic dependence of bacterial culturability on the combined effect of environmental variables and culture methodology.

Such studies make clear that strong conclusions about the effects of meteorological variables on the total bacteria concentration cannot be drawn from measurements of the culturable bacteria. At best, culture studies can be used to indicate broad patterns in concentrations, and must be followed up using alternative enumeration techniques to obtain quantitative results.

\subsection{Enumeration without cultures}

In light of the shortcomings of culture methods in characterizing bacterial populations, scientists have developed new methods for counting viable and total bacteria in aerosol samples (Ho, 2002; Kuske, 2006). The total bacteria concentration is the variable of primary importance for meteorology, since dead cells and even cell fragments may still act as condensation and ice nuclei (Möhler et al., 2008). Understanding the total bacteria concentration in the air is a necessary intermediate step towards building a mechanistic model of viable and culturable bacteria concentrations. 
The most common method for determining the total count of environmental bacteria is direct counting by epifluorescent microscopy of samples that have been treated with a fluorescent dye, most commonly 4',6-diamidino-2-phenylindole (DAPI) or acridine orange (Francisco et al., 1973; Hobbie et al., 1977; Kepner and Pratt, 1994; Matthias-Maser and Jaenicke, 1995; Harrison et al., 2005). Acridine orange binds to both DNA and RNA, while DAPI fluoresces blue when bound to DNA and yellow when unbound or bound to a non-DNA material. No dye is specific to bacteria; instead, all DNA-containing particles are stained. The bacterial cells must be counted by a human investigator taking into account the size and morphology of the stained particles. Epifluorescent microscopy permits counting of the total number of unlysed cells containing DNA, a number that includes both viable and non-viable bacteria.

The disadvantage of epifluorescent microscopy is that this is a tedious and time-consuming process. Recently, more automated techniques have been attempted, including computer analysis of microscopy pictures (Carrera et al., 2005) and fluorescence spectroscopy (Reyes et al., 1999; Courvoisier et al., 2008). A greater degree of automation is also achieved by genetic analysis techniques, which hold particular promise for detailed analysis of the bacterial aerosol. The quantitative polymerase chain reaction (Q-PCR) allows the genetic identification of biological aerosol particles to the genus level or better, while simultaneously counting the number of cells of each microorganism. The use of genetic techniques is gaining popularity in environmental microbiology, and several recent studies focus on using genetic methods to describe the biological diversity of bacteria in the air (Brodie, 2007; Despres et al., 2007; Wagner et al., 2007; Fröhlich-Nowoisky et al., 2009; Bowers et al., 2009).

\subsection{Measurement of bacteria emission fluxes}

Few direct measurements of bacterial emission fluxes are available. The few that we are aware of are listed in Table S2. The fast-response instrumentation required for eddy correlation measurements does not exist for biological particles. Instead, flux measurements are made using gradient methods such as the Bowen ratio method. These methods require a large number of measurements for statistical significance and can be difficult to interpret. Existing flux estimates include only culturable bacteria counts and no measurements of total environmental bacteria emission flux. The deposition flux has been estimated in some studies by exposing a horizontally-oriented petri dish to the air; however, the deposition of particles to a petri dish does not necessarily simulate the true rate of deposition onto plant and soil surfaces.

\section{Mechanisms of emission to the atmosphere}

Bacteria are emitted to the atmosphere from nearly all surfaces, including plant, soil and water surfaces (Jones and Harrison, 2004). It can be useful to classify emission mechanisms as either active or passive. Active mechanisms of bacteria emission include ejection by disease-carriers, such as livestock or humans (e.g., by sneezing). Passive mechanisms are the result of meteorological processes acting on a source reservoir. For instance, wind and mechanical disturbances can drive lofting of bacteria from plant or soil surfaces, and the bursting of small bubbles on wave crests and during surf breaking results in aerosol generation from water. A further distinction can be made between point sources and area sources. For bacteria, point sources include sewage treatment plants and constructions sites (via disturbance of dust), and area sources include forests, grasslands, and natural water surfaces.

Rates of passive emission can be expected to depend on a combination of the local meteorological conditions and the concentration of bacteria in the source material and on surfaces. To a first approximation, the effects of local meteorology on emissions can be expected to be similar to the effects on mineral dust and sea salt emissions, which have been much better studied.

\section{Description of reviewed data}

The literature atmospheric on bacterial concentrations is varied, including studies from the fields of microbiology, plant pathology, meteorology, medicine and public health. A number of these studies are summarized in Table 1, with individual measurements listed in Table S3. Most of the studies used culture techniques to analyze aerosol samples collected by impaction onto plates or slides, although some used filtration to collect samples and some enumerated the total cell count by microscopic examination. Enumeration of bacteria was sometimes followed by additional analysis (e.g. morphological or genetic identification, physical analysis of trace elements). Particle collection was sometimes accompanied by measurement of meteorological variables, most commonly including temperature and wind speed.

For the culture-based measurements reviewed, at least 13 different culture media were used, with incubation conducted at temperatures between at least $21^{\circ} \mathrm{C}$ and $37^{\circ} \mathrm{C}$ (sometimes at two different incubation temperatures or at "room temperature"). Incubation periods were as short as $16 \mathrm{~h}$, or as long as 16 days and sometimes completely unspecified. Although contamination is an important problem, most studies do not discuss sterilization measures or the use of blanks as a contamination control. 


\section{High altitude concentration measurements}

Knowledge of the vertical distribution of particles is important for understanding their potential to affect clouds. In addition, measurements of vertical profiles can be used in evaluating whether vertical transport is represented realistically in atmospheric models. The presence of microorganisms has been detected at very high altitudes, even in the stratosphere and mesosphere. For instance, Rogers and Meier (1936) collected fungal spores and bacteria from the stratosphere by dropping a collection device from a stratospheric balloon. Imshenetsky et al. (1978) used meteorological rockets to collect fungal spores and bacteria at altitudes of 48 to $77 \mathrm{~km}$. More recently, Wainwright et al. (2003) and Shivaji et al. (2006) have detected the presence of bacteria at altitudes up to $41 \mathrm{~km}$. These studies were all purely qualitative - they demonstrate the presence of culturable bacteria in these regions, but do not indicate their concentration.

A few studies have examined the vertical distribution of bacteria in the atmosphere. Using airplane-based samplers, Fulton (1966a) measured bacteria in the troposphere in three short-term studies and one 30-h study of microorganism concentration at three altitudes $(690 \mathrm{~m}, 1600 \mathrm{~m}$ and $3127 \mathrm{~m}$ ) over Texas. Typically, concentrations were found to be about an order of magnitude lower at $1600 \mathrm{~m}$ than at $690 \mathrm{~m}$, and even lower at $3127 \mathrm{~m}$. The variability in the concentration of cells was much greater at $690 \mathrm{~m}$ than at higher altitudes.

More recently, systematic long-term measurements of culturable bacteria and total protein concentrations have been conducted in southwestern Siberia over an altitude range of 0.5-7 km, (Andreeva et al., 2002; Borodulin et al., 2005b). The observed concentrations of culturable microorganisms varied by more than two orders of magnitude over the measurement period. The representation of different bacterial species depended on altitude, but the overall concentration was independent of altitude. The authors conclude that the microorganisms found at higher altitudes must originate from a distant upwind source.

\section{Size distributions}

The size distribution of bacteria-associated aerosol particles can be assessed by using a multiple-stage sampler to collect particles in several size ranges. The count median diameter can be estimated by fitting a log-normal distribution to the observed counts in each size range measured by the sampler (Shaffer and Lighthart, 1997). The count median diameter at continental sites is about $4 \mu \mathrm{m}$, while at coastal sites it is about $2 \mu \mathrm{m}$ (Shaffer and Lighthart, 1997; Tong and Lighthart, 2000; Wang et al., 2007).

The size of particles associated with observed airborne bacteria is significantly larger than the typical size of such bacteria, which is about $1 \mu \mathrm{m}$. This can be explained by the fact that bacterial cells are often associated with larger particles, such as soil or leaf fragments, and sometimes are found as clumps of bacterial cells (Bovallius et al., 1978b; Lighthart, 1997). It has been hypothesized that bacteria attached to larger particles are more likely to retain culturability, perhaps because the particle protects them from environmental stresses (Lighthart, 2000). This interpretation would be consistent with a laboratory study by Lighthart et al. (1993) of the dispersion of bacteria deposited on plant surfaces by wind gusts. They found that Pseudomonas syringae was increasingly likely to be culturable from aerosol particles as the size of the particles increased.

The particle size distribution has been shown to exhibit daily and annual cycles. In field studies in Oregon, Tong and Lighthart (2000) and Lighthart (2000) found that the proportion of culturable bacteria associated with the largest particles $(>7 \mu \mathrm{m})$ was highest and the proportion associated with the smallest particles $(<1.1 \mu \mathrm{m})$ was lowest during daytime and during the summer. These were also the times when the total bacterial concentrations and culturable bacteria concentrations were observed to be highest. They suggest that these cycles could be due to the presence of agricultural sources of atmospheric bacteria near the measurement site, which they expected to be stronger during summer, combined with a greater turbulent upward flux of particulate matter during daytime and summer, driven by insolation. Although concentrations were observed to be highest in summer in this study, this is not observed everywhere, as discussed in Sect. 7.7.

\section{The effect of climatological variables on ambient bacteria}

A number of studies have addressed the effect of meteorological variables on ambient bacterial concentrations. These have been previously reviewed briefly by Lighthart, 2000 and more extensively by Jones and Harrison, 2004. This section aims to summarize the major findings of these studies as reflected in previous reviews, while also considering additional studies not included in previous reviews.

It is important to note that most studies focussing on the effect of meteorological variables on bacterial concentrations have two serious weaknesses: First, studies using culture methods cannot effectively separate environmentally-driven cycles in bacterial culturability from cycles in concentration. Second, most studies fail to analyze the independent significance for bacterial concentration of cross-correlated meteorological variables, such as temperature and wind speed.

The main components that emerge as significant in determining the flux of culturable bacteria are: precipitation, wind speed, and the time of day and season, which are linked to solar input, boundary-layer circulation, and the temperature of air and of soil and plant surfaces. A correlation with the total particulate mass is often observed, which is probably not a causal connection. 


\subsection{Temperature}

Temperature directly affects the rate of bacterial metabolism and reproduction, as well as culturability (Sect. 2.2). Temperature is also correlated with a number of important meteorological and climatological variables that may affect bacteria concentrations in air, such as boundary layer turbulence, time of day, and season.

Most studies find that both culturable and total bacteria concentrations are positively correlated with the air temperature (Bovallius et al., 1978b; Lighthart et al., 2004; Harrison et al., 2005). An exception is a study in Mexico City, where the concentration of culturable bacteria was not correlated with the air temperature, but was correlated with the daily range of temperature (Rosas et al., 1994). Since concentrations were found to be strongly dependent on the season (wet vs. dry) in this study, this could simply be an indication that seasonal effects are more important than day-to-day temperature variations at this location.

\subsection{Relative humidity}

Some studies show a correlation between relative humidity and ambient bacterial concentrations (Lighthart et al., 2004; Rosas et al., 1994), while other studies find no correlation (Mouli et al., 2005).

\subsection{Wind speed}

Wind near the surface drives turbulence in the planetary boundary layer. High wind speeds can result in increased particle lofting, and so increase boundary-layer bacteria concentrations. Over water surfaces, high wind speeds result in rougher waters and more aerosol generation. On the other hand, higher wind speeds can also lead to greater boundarylayer dilution, which could decrease boundary-layer bacteria concentrations.

Wind speed has generally been found to have a significant positive correlation with culturable bacteria concentrations (Mouli et al., 2005; Bovallius et al., 1978b; Lighthart et al., 2004). Lindemann and Upper (1985) studied bacteria over crops using a culture-based method and found that both concentration and upward flux were positively correlated with wind speed. Many authors have observed that particles are only lofted when near-surface winds exceed a threshold of $1-3 \mathrm{~m} \mathrm{~s}^{-1}$ (Jones and Harrison, 2004).

\subsection{Rain events}

Two studies (Constantinidou et al., 1990; Lindemann and Upper, 1985) address the effect of both rain and soil wetness on bacteria flux. They found that bacteria concentrations directly above crops increased dramatically during rain events, up to 25 -fold. At the same time, they observed a strong net deposition flux of bacterial aerosol. Lindemann and Upper (1985) also observed a large increase in the concentration of bacteria in rain as it passed through the canopy, which they attributed to the removal of bacteria from leaves by rain.

Soil wetness after rain may promote bacterial growth in soil; however, wet soil is a poor source of aerosol. Lindemann and Upper (1985) found that the net upward flux of culturable bacteria was a factor of 10-100 higher on days after rainfall, when soil remained wet, compared to days with dry soil. The reason for this phenomenon is unclear. The authors assume that when the soil is wet, leaves are the only significant aerosol source. They suggest that rain at some interval before the sampling time may either promote either the growth of bacteria or their release from leaf surfaces.

\subsection{Total particulate mass}

Because bacteria in the aerosol are affected by the same meteorological processes that affect all aerosol particles, the concentration of bacteria is likely to be highly correlated with the total particulate mass $\left(\mathrm{PM}_{10}\right)$, if the sources of bacteria and total aerosol are correlated. Such a correlation is often observed. For instance, Rosas et al. (1994) found that the culturable bacteria concentration was more strongly correlated with $\mathrm{PM}_{10}$ than with temperature or specific humidity. Understanding this relationship better might help to distinguish the effects of meteorology from the effects of the strength and distribution of emission sources in determining atmospheric concentrations.

\subsection{Diurnal cycles}

A typical diurnal cycle in culturable bacterial concentrations, with highest concentrations in morning and evening hours, was first observed by Miquel in Paris (Miquel, 1886; cited in Gregory, 1973), and has been observed subsequently in other studies (Lighthart and Kirilenko, 1998; Tong and Lighthart, 1999). Studies of the diurnal variation of the bacterial flux from continental locations have consistently found that the net upward flux reaches a maximum during the warmest hours of the day (Lindemann and Upper, 1985; Lighthart and Shaffer, 1994; Lighthart and Kirilenko, 1998; Chen et al., 2001).

Because bacteria gradually lose culturability upon exposure to atmospheric stresses, the culturable bacteria count is most sensitive to freshly emitted bacteria. During the warmest part of the day, the rate of emission is at a peak, so the freshly emitted fraction and the culturable fraction of the total bacteria should also reach a peak. This was observed by Tong and Lighthart (1999), who found that the culturable fraction of the bacteria over a grass field was largest during the warmest part of the day and smallest at night (Fig. 1).

\subsection{Seasonal cycles}

the Seasonal variation of bacterial aerosol concentrations has been observed by many authors (Pady and Kelly, 1954; Bovallius et al., 1978b; Rosas et al., 1994; di Giorgio et al., 
1996; Tong and Lighthart, 2000; Borodulin et al., 2005a; Harrison et al., 2005). Generally, the lowest mean concentrations are observed during winter and the highest during summer, although this is not always the case, and it is unknown to what extent this variability is driven by biological activity, and to what extent it is the direct result of meteorological variables such as temperature, wind speed and precipitation. Three sets of systematic, long-term observations of culturable bacteria concentrations are shown in Figure 2, all from the nothern hemisphere. In these three studies, the highest monthly mean concentrations were observed during November or September, while lowest concentrations were observed during December, January, or February. For each data set, the variations within each month are of a similar order of magnitude to the monthly mean values, and may be larger than the seasonal changes in the monthly mean.

The higher concentrations during summer observed at many locations may be due to seasonal differences in temperature and its effects on source strength and atmospheric convection (Lighthart, 2000; Tong and Lighthart, 2000). On the other hand, Rosas et al. (1994) found a statistically significant drop in the concentration of culturable bacteria during the wet summer season in Mexico City, which was attributed to greater removal by precipitation during wet months.

\section{Bacterial aerosol over land by ecosystem}

The number of prokaryotic cells (organisms that lack a cell nucleus, including bacteria and archaea) in forest soils has been estimated at $4 \times 10^{7} \mathrm{~g}^{-1}$, while the number of prokaryotic cells in all other soils (including desert and cultivated soils) is believed to be about $2 \times 10^{9} \mathrm{~g}^{-1}$ (Whitman et al., 1998). Bacteria also live on leaves and other aerial plant surfaces, with concentrations on leaves of about $10^{8} \mathrm{~g}^{-1}$ (Lindow and Brandl, 2003). The global population of microbes on leaves may be as many as $10^{26}$ cells (Morris and Kinkel, 2002).

The published measurements listed in Table S3 give an overview of the concentrations of bacteria in near-surface air in various locations around the world, organized by ecosystem or land use type. Although the picture is still incomplete, some rough estimates of concentrations can be obtained from this table (Table 1, discussed below). In choosing these numbers, we considered only a selection of the available data. In general, measurements of total bacterial concentration were given preference. Where only culturable bacteria concentrations were available, an attempt was made to estimate an appropriate scaling factor by comparing other measurements from the same study with total concentration measurements in similar environments.

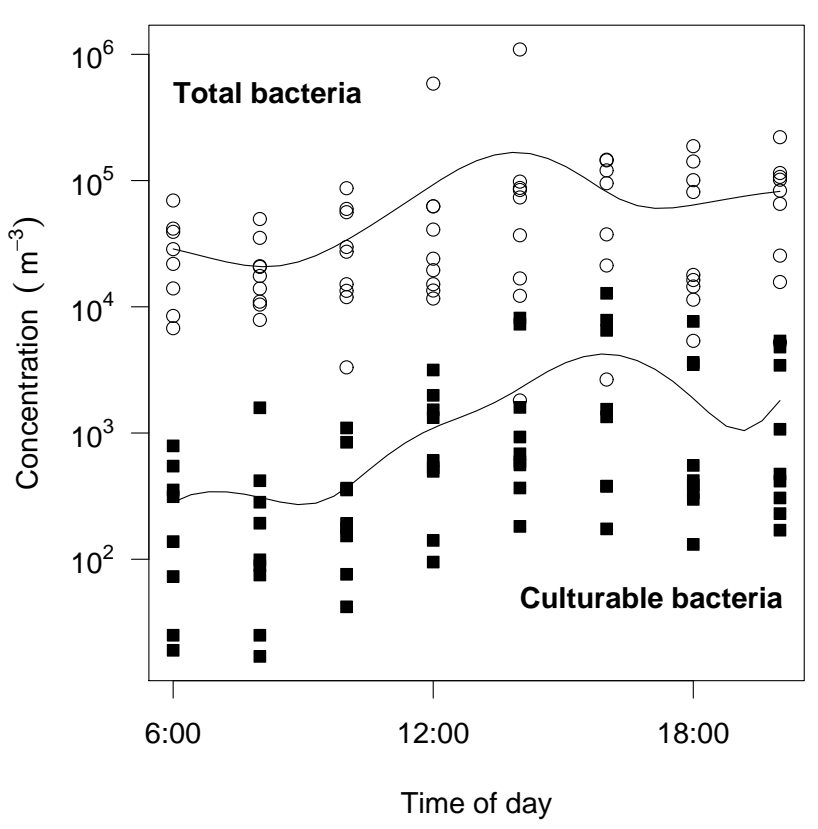

Fig. 1. Diurnal variation in total and culturable bacteria concentrations over a grassy field near Corvallis, OR on nine clear sunny days during the summer and autumn of 1996, with a spline interpolation. Adapted from Tong and Lighthart (1999).

\subsection{Crops, rural and remote continental locations}

At remote and rural locations, concentrations are generally found to be lower than in cities. Bauer et al. (2002) measured mean bacterial aerosol concentrations of $1.2 \times 10^{4} \mathrm{~m}^{-3}$, in good agreement with measurements by Harrison et al. (2005) at two rural sites in England, where mean spring concentrations were found to be $1.1 \times 10^{4}$ and $1.6 \times 10^{4} \mathrm{~m}^{-3}$, respectively.

Above crops, concentrations may be higher, and sometimes increased by human activities. Tong and Lighthart (1999) sampled total and culturable bacteria above a rye grass field on 11 days during summer and autumn. The mean concentration of total bacteria above mature grass (one sampling day), swathed grass (two days) and dry grass (four days) was $8.5 \times 10^{4} \mathrm{~m}^{-3}$. This is considerably higher than the average of $1.4 \times 10^{4} \mathrm{~m}^{-3}$ measured at two rural sites in England by Harrison et al. (2005). The discrepancy could reflect differences in bacterial aerosol concentration near various kinds of crops, which can vary by an order of magnitude (Lindemann et al., 1982). Sampling biases, weather conditions, and the use of different measurement methodologies could also contribute to this difference.

The best, low and high estimates given for crops in Table 1 are based on the average of measurements at two rural sites by Harrison et al. (2005), where the best estimate is the average of the seasonal means, and the high and low estimates are the averages of the seasonal means plus or minus the standard 
Table 1. Estimates of total mean bacterial concentration in near-surface air of various ecosystem types $\left(\mathrm{m}^{-3}\right)$. See Sect. 8 for details.

\begin{tabular}{|c|c|c|c|}
\hline Ecosystem & Best estimate $^{\mathrm{a}}$ & Low estimate ${ }^{a}$ & High estimate \\
\hline coastal $^{b}$ & $7.6 \times 10^{4}$ & $2.3 \times 10^{4}$ & $1.3 \times 10^{5}$ \\
\hline crops $^{b}$ & $1.1 \times 10^{5}$ & $4.1 \times 10^{4}$ & $1.7 \times 10^{5}$ \\
\hline deserts $^{c}$ & & $1.6 \times 10^{2}$ & $3.8 \times 10^{4}$ \\
\hline forests $^{\mathrm{d}}$ & $5.6 \times 10^{4}$ & $3.3 \times 10^{4}$ & $8.8 \times 10^{4}$ \\
\hline grasslands $\mathrm{b}, \mathrm{e}$ & $1.1 \times 10^{5}$ & $2.5 \times 10^{4}$ & $8.4 \times 10^{5}$ \\
\hline land ice $\mathrm{f}^{\mathrm{f}}$ & & & $1 \times 10^{4}$ \\
\hline seas $^{b, f, g}$ & $1 \times 10^{4}$ & $1 \times 10^{1}$ & $8 \times 10^{4}$ \\
\hline shrubs $\mathrm{e}, \mathrm{f}$ & $3.5 \times 10^{5}$ & $1.2 \times 10^{4}$ & $8.4 \times 10^{5}$ \\
\hline tundra ${ }^{\mathrm{d}, \mathrm{f}}$ & $1.2 \times 10^{4}$ & & $5.6 \times 10^{4}$ \\
\hline wetlands $\mathrm{h}$ & $9 \times 10^{4}$ & $2 \times 10^{4}$ & $8 \times 10^{5}$ \\
\hline urban (curbside) ${ }^{\mathrm{d}}$ & $6.5 \times 10^{5}$ & $4.4 \times 10^{5}$ & $9.2 \times 10^{5}$ \\
\hline urban park ${ }^{\mathrm{b}}$ & $1.2 \times 10^{5}$ & $4.8 \times 10^{4}$ & $1.9 \times 10^{5}$ \\
\hline
\end{tabular}

${ }^{\text {a }}$ Fields are left blank where an estimate could not plausibly be derived from the literature.

$\mathrm{b}$ Harrison et al. (2005)

c Lighthart and Shaffer (1994)

d Shaffer and Lighthart (1997)

e Tong and Lighthart (1999), Tilley et al. (2001)

f Bauer et al. (2002)

$\mathrm{g}$ Griffin et al. (2006)

$\mathrm{h}$ Assumed to be within bounds of best estimates in coastal and grassland/crops regions.

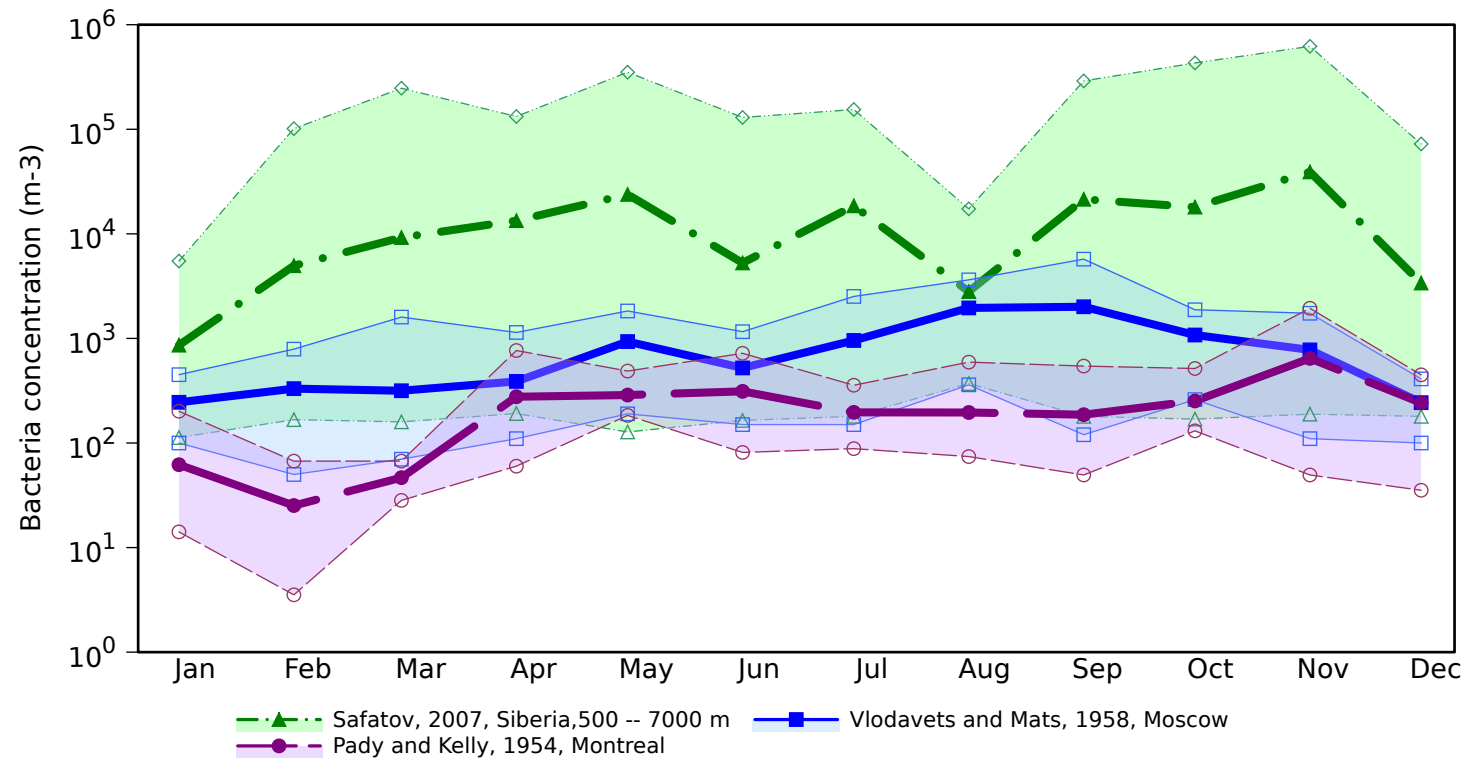

Fig. 2. Monthly average, minimum and maximum concentrations of culturable bacteria over Siberia (near Novosibirsk, Russia) (Borodulin et al., 2005a), Montreal, Canada (Pady and Kelly, 1954), and Moscow, Russia (Vlodavets and Mats, 1958). Heavy lines show mean values, while thin lines show maxima and minima. Concentrations over Siberia are average values of airborne measurements between 500 and $7000 \mathrm{~m}$ altitude. Concentrations over Montreal are from the top of a $120 \mathrm{~m}$ tall building, and concentrations over Moscow are from nearsurface air. 
deviations, respectively. In the calculation of the low estimate, measurements with a standard deviation greater than the mean were set to zero.

\subsection{Forests}

Forest soils are nutrient-poor, and contain lower concentrations of microbes than do soils in other regions (Whitman et al., 1998). However, they contain a large surface area of aerial plant parts, which provide ample habitat for bacteria. The transfer of particles to the free troposphere can be inhibited by the large rate of dry deposition onto plant surfaces beneath the canopy, so an effective emission flux from the canopy is needed for global atmospheric models.

Shaffer and Lighthart (1997) measured culturable bacteria concentrations in a forest, as well as at urban, coastal and rural sites in Oregon. We estimated the culturable fraction in the Shaffer and Lighthart (1997) measurements by using independent observations of the total bacteria at similar sites (Harrison et al., 2005) and calculating the ratios of the mean total bacteria measured by Harrison et al. (2005) to the mean culturable bacteria measured by Shaffer and Lighthart (1997) for each season, and averaged these ratios for each site. ${ }^{1}$ The mean ratios of total to culturable bacteria for the coastal and rural sites were 133 and 81, respectively, which we used as rough scaling factors for the Shaffer and Lighthart (1997) data.

For the forest site, Shaffer and Lighthart report a mean culturable bacteria concentration of $609 \mathrm{~m}^{-3}$, with a $95 \%$ confidence interval of 539-688 $\mathrm{m}^{-3}$. We multiplied the lower bound of the confidence interval by 81 to obtain a low estimate for forests of $3.3 \times 10^{4}$ and the upper bound by 133 to obtain a high estimate of $8.8 \times 10^{4}$. We multiplied the mean concentration by 104 (the mean scaling factor) to obtain a best estimate of $5.6 \times 10^{4}$ (Table 1$)$.

\subsection{Deserts}

Desert dust is an important part of the atmospheric aerosol in some regions, and dust clouds intermittantly transported over long distances, making a substantial contribution to the aerosol content of the air in distant regions. For instance, about half of the particles in Florida's atmosphere each summer are African in origin (Prospero, 1999). These dust clouds also contain bacteria; bacteria in the aerosol and in cloud water are often found to be attached to mineral dust or other larger aerosol particles (Lighthart et al., 1993; Casareto et al., 1996), and a gram of desert dust may contain as many as $10^{9}$ bacterial cells (Whitman et al., 1998).

In observations primarily at coastal and marine sites, bacterial concentrations in the air have been observed to increase during dust storms (Griffin et al. 2001a, 2003; Kellogg

\footnotetext{
${ }^{1}$ Due to the incomparability of the urban sites studied in Harrison et al. (2005) and Shaffer and Lighthart (1997), we did not consider them as a basis for comparison.
}

and Griffin 2006; Griffin et al. 2006; Prospero et al. 2005; Schlesinger et al. 2006; see also bottom of Table S3). Prospero et al. (2005), for example, found that the peak patterns of culturable fungi and bacteria in sea air in the Carribean both match those of dust, but are unrelated to those of sea salt and non-sea-salt sulfate. However, in many case studies it is difficult to determine whether the source of the increased bacteria is a distant desert, local emissions, or some other source.

The relative contributions of desert dust and the total biological particles (including bacteria, but also other biological particles) to the ice nuclei count has been investigated in two recent studies. Prenni et al. (2009) observed ice nuclei at a measurement tower in the Amazon basin. They report that in the absence of Saharan dust, the ice nuclei observed were primarily carbonaceous, while during intermittent dust events the ice nuclei are primarily dust. Pratt et al. (2009) sampled cloud ice-crystal residues at about $8 \mathrm{~km}$ altitude over Wyoming, USA, and report that mineral dust accounted for c. $50 \%$ of the residues and biological particles for c. $33 \%$.

The long-distance transport of bacteria together with dust has been discussed in several studies as a mechanism for the global dispersion of microbial species, with the potential to impact ecosystems and public health (Griffin et al., 2001b; Griffin, 2005; Kellogg and Griffin, 2006). The dispersion of desert dust and the accompanying microorganisms can be expected to increase due to increased desertification in the coming years (Griffin et al., 2007).

However, it should be kept in mind that deserts are not unique as a source for inter-regional transport of bacteria. Transport of bacteria between different ecosystems is a likely to be routine consequence of atmospheric transport patterns, as shown by the model study accompanying this literature review (Burrows et al., 2009). Based on the the observations of (Lighthart and Shaffer, 1994) and the lower biological productivity of deserts, we expect deserts to have low rates of emission compared to most other ecosystems. On the other hand, bacteria emitted in desert regions have a comparatively long residence time in the atmosphere and are therefore more likely to participate in long distance transport (Burrows et al., 2009). For further discussion of the long-distance transport from deserts and other ecosystems, see Burrows et al. (2009).

None of the papers reviewed that studied desert ecosystems used direct enumeration techniques and none included a mean value or other statistical measure of the middle. A study of an isolated high desert location in Oregon found concentrations of culturable bacteria ranging from 2 to $280 \mathrm{~m}^{-3}$ (Lighthart and Shaffer, 1994). Since this study used the same methodology as Shaffer and Lighthart (1997), we estimated the range of total bacteria as for the forests, multiplying the lower bound by 81 and the upper bound by 133 , giving bounds of $1.6 \times 10^{2}-3.8 \times 10^{4} \mathrm{~m}^{-3}$. 


\subsection{Grasslands}

Grassland sites can be expected to have concentrations similar to or higher than those of grass crops, since crops are often treated with chemicals that may reduce the number of bacteria on plant surfaces. Total bacteria concentrations above an agricultural rye grass field were measured by Tong and Lighthart (1999), who measured an average of $8.5 \times 10^{4} \mathrm{~m}^{-3}$ for mature, swathed and dry crops. This value is reported as an upper limit for the grassland mean concentration in Table 1 .

Additionally, culturable bacteria concentrations at a tropical grassland site were studied by Tilley et al. (2001). They also measured concentrations at a seaside university campus in spring. This site, located in a suburban area with many parks, is similar to the urban site of Harrison et al. (2005), which was located in a university botanical garden. Comparison of the springtime mean values in the two studies $\left(1.8 \times 10^{4}\right.$ total and 58 culturable bacteria $\mathrm{m}^{-3}$, respectively) gives a factor of 302 for the conversion of Tilley et al. (2001) measurements to total bacteria. Multiplying this by the concentration of culturable bacteria $\left(83 \mathrm{~m}^{-3}\right)$ measured in autumn by Tilley et al. (2001) gives a lower estimate of $2.5 \times 10^{4} \mathrm{~m}^{-3}$. Within this broad range, the estimated mean value for crops (from Harrison et al., 2005) is taken as a best first estimate of the mean concentration over grasslands.

\subsection{Shrubs}

None of the measurements reviewed were made in environments dominated by shrubs. We assume that the bacterial concentration in shrub-dominated ecosystems is intermediate between that measured by Bauer et al. (2002) at a remote alpine location in Europe and that measured by Tong and Lighthart (1999) over a grass field.

The estimated mean is taken from measurements by Tilley et al. (2001) in a tropical grassland with scattered trees (average of spring and autumn measurements; multiplied by correction factor of 302 to obtain an estimate of the total bacteria).

\subsection{Tundra}

Similarly, none of the measurements reviewed were made in tundra environments. We assume that mean concentrations in a tundra region would be similar to those at a remote alpine site and no higher than mean concentrations at a forest site.

\subsection{Wetlands}

Again, no measurements are available for concentrations of bacteria over wetlands. We assume that these are within the bounds estimated for coastal regions (lower bound) and crops and grasslands (upper bound). The estimated mean value given in Table 1 is intermediate between the estimated mean concentrations over crops and coastal sites.

\subsection{Polar and glacial (land ice)}

Bacteria have been shown to live and metabolize within land and sea ice, as well as snow (Arrigo and Sullivan, 1992; Alldredge et al., 1986; Price, 2000; Junge et al., 2004; Arrigo and Thomas, 2004). At the South Pole, Carpenter et al. (2000) found a population of about 200 to 5000 cells per $\mathrm{ml}$ of melted surface snow. Surface snows may be lofted with bacteria attached. However, the low concentrations of bacteria in polar air suggest that the atmospheric source from frozen surfaces is small. Pady and Kelly (1954) observed that polar air arriving in Montreal had extremely low concentrations of both bacteria and fungi compared with other air masses. The measurements of bacterial aerosol reviewed did not include any examples at glacial sites. In the absence of better information, we assume that the "background" continental concentration of about $10^{4} \mathrm{~m}^{-3}$ (Bauer et al., 2002) represents the upper limit of concentrations in polar and glacial regions.

\subsection{Urban}

Concentrations of bacteria in cities vary strongly due to the large number of point sources. Areas with heavy vehicular traffic have much higher concentrations of aerosol particles, including bacteria, than quieter areas such as parks. This was observed as early as 1883 by Miquel, and has also been observed by recent studies (e.g. Fang et al., 2007).

Values given for the urban park in Table 1 are averages of measurements at an urban site (Harrison et al., 2005) calculated as for the coastal site. The location of this site was in the university botanical gardens in Birmingham, England.

A curbside site was investigated by Shaffer and Lighthart (1997) in Corvallis, Oregon. The values given in Table 1 were converted from culturable bacteria to an estimate of total bacteria by the same method used for the forest site.

\subsection{Coastal}

We assume that the mean concentrations at coastal sites are intermediate between mean land and ocean concentrations. This is supported by the observation that sites located at a short distance inland and dominated by continental influence have higher concentrations of bacteria, while sites dominated by sea breezes have lower concentrations of bacteria (Prospero et al., 2005).

The best, high, and low estimates in Table 1 were calculated from the seasonal means and standard deviations of the total bacteria concentration at a coastal site (Harrison et al., 2005); calculations were performed as for the estimates of concentrations over crops. 


\section{Bacteria in marine air}

Bacteria play a vital role in the marine ecosystem, with heterotrophic bacteria ${ }^{2}$ consuming roughly $50 \%$ of the net primary production of organic carbon (Williams, 1981; Cole et al., 1988; Azam, 1998). The abundance of bacteria in surface waters ranges from about $10^{5}$ to $10^{7} \mathrm{~cm}^{-3}$, and is significantly positively correlated with chlorophyll concentrations, and thus with phytoplankton biomass (Linley et al., 1983; Bird and Kalff, 1984; Cho and Azam, 1990; Li et al., 2004). The best estimate for the volume of a marine bacterial cell is about $0.05 \mu \mathrm{m}^{3}$, corresponding to a mass of about $50 \mathrm{fg}$ and a radius of about $0.2 \mu \mathrm{m}$ (Lee and Fuhrman, 1987).

Recently, strong evidence has been obtained for a large oceanic source of organic carbon to the atmosphere. Observations at three marine sites show a correlation between the organic carbon aerosol mass and oceanic chlorophyll concentrations weighted along air mass back trajectories (Mace Head $\left(53^{\circ} \mathrm{N}, 9^{\circ} \mathrm{W}\right)$, Amsterdam Island $\left(37^{\circ} \mathrm{S}, 77^{\circ} \mathrm{E}\right)$, and the Azores ( $\left.38^{\circ} \mathrm{N}, 27^{\circ} \mathrm{W}\right)$; O'Dowd et al., 2008; Spracklen et al., 2008). O'Dowd et al. (2004) showed that the submicron marine aerosol at Mace Head, Ireland is dominated by water insoluble organic compounds during the biologically active season, which they assume are derived from a large marine primary aerosol source. Such an aerosol source could have important climate implications, particularly in remote marine regions. This hypothesis is supported by the observation of Meskhidze and Nenes (2006) that the effective cloud droplet mean radius in the Southern Ocean is significantly correlated with phytoplankton concentrations.

Possible marine sources of secondary organic aerosol include oxidation products of DMS and isoprene (Charlson et al., 1987; Meskhidze and Nenes, 2006). However, recent work indicates that the marine isoprene source is too small for its oxidation products to contribute significantly to the marine aerosol (Spracklen et al., 2008). Secondary organic aerosol formed from DMS oxidation products is water-soluble, so DMS also cannot explain the large insoluble organic aerosol concentrations observed at Mace Head (O’Dowd et al., 2004).

The bacteria in the marine atmosphere contribute to this insoluble organic aerosol component. The concentration of total and culturable bacteria is generally found to be lower in sea air than in continental air masses (Pady and Kelly, 1953, 1954; Fulton and Mitchell, 1966; Marks et al., 2001; Prospero et al., 2005; Harrison et al., 2005; Griffin et al., 2006). In sea air at a Carribean coastal site and over the mid-Atlantic ridge, concentrations of culturable bacteria have been shown to be closely related to dust concentrations, suggesting that dust plumes are the major source of bacteria in marine air, at least in non-biologically active regions (Prospero et al., 2005; Griffin et al., 2006). So far we are unaware of any published

\footnotetext{
${ }^{2}$ Heterotrophic organisms are those which require organic molecules as a source of chemical energy to maintain life
}

measurements of the total bacteria concentration in remote marine air.

Concentrations of atmospheric bacteria over sea are likely lower than concentrations over land by a factor of up to about 100-1000 (Prospero et al., 2005), giving a lower limit of about $10 \mathrm{~m}^{-3}$ (based on a continental "background" concentration of about $10^{4} \mathrm{~m}^{-3}$, Bauer et al., 2002). On the other hand, concentrations over sea are not likely to be higher than observed concentrations at coastal sites, which were about $8 \times 10^{4} \mathrm{~m}^{-3}$ (Harrison et al., 2005). Measurements at a drilling station over the Mid-Atlantic ridge found a mean culturable bacteria concentration of $16.4 \mathrm{~m}^{-3}$ in air (Griffin et al., 2006). Based on these observations and the relationships between culturable and total bacteria discussed above, a mean bacterial concentration of roughly $10^{4} \mathrm{~m}^{-3}$ is a reasonable first assumption.

The primary mechanism for sea-to-air transfer of bacteria is believed to be the bursting of small bubbles at the ocean surface, the same mechanism that accounts for the saltiness of marine air. The bubbles are generated primarily by whitecaps, and their abundance increases rapidly with wind speed, for winds above about 3 to $4 \mathrm{~m} \mathrm{~s}^{-1}$ (Monahan, 1986; Blanchard, 1989). Just before bursting, these bubble pass through the marine surface microlayer, which contains high concentrations of microorganisms and organic matter (Bezdek and Carlucci, 1972). During calm wind conditions, the concentrations of such compounds in the surface microlayer are highly elevated with respect to the bulk concentrations. Particulate and dissolved matter near the ocean's surface are injected into the atmosphere by the bursting of small gaseous bubbles (Blanchard, 1989). As bubbles rise through seawater, they scavenge material from the surrounding water into the bubble surface, preferentially collecting surface-active organic materials such as bacteria (Blanchard and Syzdek, 1982). Aller et al. (2005) found that bacterial concentrations are enriched by a factor of about 10-25 during transport from subsurface sea water to the atmospheric aerosol, while Marks et al. (2001) measured enrichment factors of up to $2.5 \times 10^{3}$ (Table 2).

Experimental values for the enrichment factor range over 2-3 orders of magnitude (Table 2), and the concentration of bacteria in marine surface waters varies at least one order of magnitude, from a minimum of about $3 \times 10^{5} \mathrm{~cm}^{-3}$ in very nutrient-poor waters to more typical values near $5 \times 10^{6} \mathrm{~cm}^{-3}$ (Bird and Kalff, 1984; Cho and Azam, 1990; Li et al., 2004). Keeping these uncertainties in mind, we try to estimate the approximate marine global bacteria emissions by comparison to emissions of sea salt. The estimate can be calculated as

$$
\frac{\text { Global marine bacterial emissions }}{\frac{\text { Bacterial concentration in surface waters }}{\text { Global sea salt emissions }} \times \text { Enrichment factor }}=
$$


Table 2. Laboratory and field measurements of enrichment factors.

\begin{tabular}{|c|c|c|}
\hline Enrichment factor & Notes & Reference \\
\hline $\begin{array}{l}10-100 \text { for bubble rise distances }<1 \mathrm{~cm} \text {, rising } \\
\text { to a plateau of } 500-600 \text { for bubble rise distances } \\
>5 \mathrm{~cm} \text {. }\end{array}$ & $\begin{array}{l}\text { Bubbles rose through a suspension of bacteria } \\
\text { in a controlled laboratory experiment. }\end{array}$ & Blanchard et al. (1981) \\
\hline $\begin{array}{l}1200 \text { for the top jet drop, decreasing to } 8 \text { for the } \\
\text { fifth or lowest drop in the jet set. }\end{array}$ & $\begin{array}{l}\text { The jet set is a set of larger droplets emerging } \\
\text { from the collapse of a bubble at the surface, } \\
\text { largest at the center and decreasing in size away } \\
\text { from the center. }\end{array}$ & Blanchard and Syzdek (1978) \\
\hline 10-20 for film drops from $1.7 \mathrm{~mm}$ bubbles. & $\begin{array}{l}\text { Measured after bubbles rose }<2 \mathrm{~cm} \text { through a } \\
\text { suspension of } S \text {. marcescens in either pond wa- } \\
\text { ter or distilled water. Film drops are smaller } \\
\text { droplets originating from the breaking of the } \\
\text { thin film at the top of a bubble. }\end{array}$ & Blanchard and Syzdek (1982) \\
\hline 50-100 on drops $<10 \mu \mathrm{m}$ & $\begin{array}{l}\text { Measured in the laboratory using a seawater } \\
\text { suspension of } S \text {. marinorubra. }\end{array}$ & Cipriano (1979) \\
\hline $\begin{array}{l}\text { Average of } 10 \text { (max: } 22 \text { ) in transfer from bulk } \\
\text { sea water to aerosol. Average of } 6 \text { (max: } 10) \\
\text { in transfer from bulk sea water to sea-surface } \\
\text { microlayer. }\end{array}$ & $\begin{array}{l}\text { Samples were collected near Long Island, New } \\
\text { York, when winds were south to southeast at } 3- \\
4 \mathrm{~m} \mathrm{~s}^{-1}\end{array}$ & Aller et al. (2005) \\
\hline $\begin{array}{l}37-2545 \text { for mesophilic bacteria (which grow } \\
\text { best at moderate temperstures); } 14-585 \text { for psy- } \\
\text { chrophilic bacteria (which grow best at cold } \\
\text { temperatures). }\end{array}$ & $\begin{array}{l}\text { Laboratory measurements of the enrichment } \\
\text { factor were conducted using seawater sample } \\
\text { taken from coastal locations around the Gulf of } \\
\text { Gdansk }\end{array}$ & Marks et al. (2001) \\
\hline
\end{tabular}

The global emissions of sea salt are about $10^{4} \mathrm{Tg} \mathrm{a}^{-1}$, with a concentration of sea salt in surface ocean waters of about $35 \mathrm{~g} \mathrm{~kg}^{-1}$ (Elbert et al., 2007). Table 3 gives values for the variables needed to make this estimation: the concentration in sea water and the enrichment factor, together with the estimated bacterial emissions. Assuming that the mean concentration of bacterial cells in surface sea waters is $4.2 \times 10^{6} \mathrm{~cm}^{-3}$ (Li et al., 2004), and that the enrichment factor is between 15 and 100, the mean rate of emission of bacterial cells from sea water could be between 200 and $1000 \mathrm{~m}^{-2} \mathrm{~s}^{-1}$. With different assumptions, we obtain estimates ranging from a low of $4 \mathrm{~m}^{-2} \mathrm{~s}^{-1}$ to a high of $2 \times 10^{4} \mathrm{~m}^{-2} \mathrm{~s}^{-1}$ (see Table 3 ).

We now compare the estimated boundary-layer concentrations that would result from these emissions with our previous estimate of concentrations in marine air. Assuming a residence time $(\tau)$ of 1-5 days (Burrows et al., 2009), an emission flux $(F)$ of $200-1000 \mathrm{~m}^{-2} \mathrm{~s}^{-1}$, and a scale height $(h)$ of 100-1000 m, we obtain an estimated boundary-layer concentration $(C)$ of $0.2-50 \times 10^{5} \mathrm{~m}^{-3}(C=F \cdot \tau / h)$. The observed concentrations are slightly lower, about $10^{4} \mathrm{~m}^{-3}$, although considering the large uncertainties in estimating both concentrations and emissions, these values are reasonably consistent.
Possible interpretations of the small dicrepancy between observed concentrations and estimated emissions include: (i) typical enrichment factors are at the low end of the observed range, (ii) the residence time in the atmosphere is shorter than expected, perhaps because bacteria are often attached to larger sea salt particles, or (iii) the mean concentration of bacteria in marine air has been underestimated.

Two factors suggest that marine concentrations may be higher than our estimate. First, it is likely that marine bacteria are less culturable than continental bacteria with conventional methods. The culturability of bacteria in seawater is estimated to be between $0.001 \%$ and $0.1 \%$, compared to $0.25 \%$ for freshwater and $0.3 \%$ for soil (Colwell, 2000). Second, the concentration of bacteria in the surface waters of nutrient-rich regions may be a factor of ten or more higher (Cho and Azam, 1990), so emissions are likely to be higher in these regions. 
Table 3. Estimates of marine emissions calculated using different characteristic values.

\begin{tabular}{lrrr}
\hline $\begin{array}{l}\text { Concentration of } \\
\text { marine bacteria }\left(\mathrm{cm}^{-3}\right)\end{array}$ & $\begin{array}{r}\text { Enrichment } \\
\text { factor }\end{array}$ & $\begin{array}{r}\text { Global emissions } \\
\text { estimate }\left(\mathrm{Gg} \mathrm{a}^{-1}\right)\end{array}$ & $\begin{array}{r}\text { Potential emission rate } \\
\left(\mathrm{m}^{-2} \mathrm{~s}^{-1}\right)\end{array}$ \\
\hline $3 \times 10^{5^{\mathrm{a}}}$ & 5 & 2 & 4 \\
& 15 & 6 & 10 \\
$4.2 \times 10^{6^{\mathrm{b}}}$ & 100 & 40 & 80 \\
& 5 & 30 & 50 \\
$14 \times 10^{6^{\mathrm{c}}}$ & 15 & 90 & 200 \\
& 100 & 600 & 1000 \\
& 5 & 100 & 200 \\
& 15 & 300 & 500 \\
& 100 & 2000 & 4000 \\
& 500 & 10000 & 20000 \\
\hline
\end{tabular}

a Apparent minimum concentration of bacteria in nutrient-poor marine surface waters, measured by Cho and Azam (1990).

b Representative value suggested by Li et al. (2004) on the basis of median chlorophyll concentration from satellite observations.

c A very high bacterial concentration measured in Lake Ementeita, Kenya (Kilham, 1981).

\section{Summary}

The concentration and flux of bacteria in the air can be measured using established methodologies. However, care must be taken to reduce systematic measurement errors. In particular, interpreting culturable bacteria counts is difficult, and counts of the total bacteria should be obtained if possible. Features, trends and dependencies on meteorological conditions that are seen in measurements of culturable bacteria are sometimes consistent with those seen when total bacteria are measured, but sometimes they differ. Measurements of local fluxes coupled with meteorological observations can help to improve understanding of the mechanisms driving bacterial emissions.

Rough estimates of bacterial concentrations can be given for some ecosystem and land use types. In some ecosystem types, no measurements are available (e.g. wetlands, tundra, shrubs, land ice), and the estimates given here are based on assumed similarities to other ecosystems. Meteorological variables are known to affect the surface emissions and atmospheric concentrations of bacteria. The balance of the evidence suggests that temperature and wind speed are the most important determining factors where bacteria are emitted by local area sources. The amount of precipitation and the relative humidity may also play important roles, and some observations show that bacterial concentrations tend to be correlated with the concentrations of other particulate matter. Wind direction can also be important when the sources near the measuring location are heterogeneous.

Finally, transport from distant sources may play an important role, sometimes resulting in episodic increases in concentrations. Bacteria are commonly observed to be transported over long distances together with desert dust. Statistical studies of the impact of various meteorological factors on the total bacterial concentration might help to clarify the issue. However, transport scales are large enough that the link between local meteorological conditions and bacterial concentrations will be weak in many circumstances. Bacterial concentrations also show significant seasonal and diurnal cycles, which have been attributed to the combined effect of cycles in boundary-layer turbulent transport, biological productivity, and culturability where culture-based methods were used.

In order to establish a direct effect of bacteria on atmospheric chemistry and climate, several more pieces of information will be required: 1) the concentration of bacteria in the atmospheric aerosol; 2) the rate of uptake of bacteria into cloud droplets and their ability to function as $\mathrm{CCN}$ and IN; 3) the fraction of bacteria in cloud droplets capable of metabolism at ambient cloud conditions, and the rates of biodegradation of atmospherically important compounds under these conditions; 4) the residence times of microorganisms in cloud droplets; and 5) the use, by bacteria, of survival strategies that allow them to prevent dessication, and the speed with which resuscitation occurs when bacteria are in cloud droplets.

A companion paper investigates particle transport and removal processes in a global chemistry-climate model as a step towards unravelling the effects of ecosystem type and meteorology on bacterial concentrations (Burrows et al., 2009). 
Acknowledgements. The authors wish to thank Viviane Deprés and Ruprecht Jaenicke for fruitful discussions. The International Max Planck Research School on Atmospheric Chemistry and Physics is acknowledged gratefully for hosting Susannah Burrows' research, which has been supported under a National Science Foundation Graduate Research Fellowship (grant number 0633824).

The service charges for this open access publication

have been covered by the Max Planck Society.

Edited by: R. Cohen

\section{References}

Addiss, D., Davis, J., Laventure, M., Wand, P., Hutchinson, M., and McKinney, R.: Community-acquired Legionnaires' disease associated with a cooling tower: Evidence for longer-distance transport of legionella pneumophila, Am. J. Epidemiol., 130, 557$568,1989$.

Alldredge, A., Cole, J., and Caron, D.: Production of heterotrophic bacteria inhabiting macroscopic organic aggregates (marine snow) from surface waters., Limnol. Oceanogr., 31, 6878, 1986.

Aller, J., Kuznetsova, M., Jahns, C., and Kemp, P.: The sea surface microlayer as a source of viral and bacterial enrichment in marine aerosols, J. Aerosol Sci., 36, 801-812, 2005.

Amann, R., Ludwig, W., and Schleifer, K.: Phylogenetic identification and in situ detection of individual microbial cells without cultivation, Microbiol. Rev., 59, 143-169, 1995.

Amato, P., Ménager, M., Sancelme, M., Laj, P., Mailhot, G., and Delort, A.-M.: Microbial population in cloud water at the Puy de Dôme: Implications for the chemistry of clouds, Atmos. Environ., 39, 4143-4153, 2005.

Amato, P., Demeer, F., Melaouhi, A., Fontanella, S., Martin-Biesse, A., Sancelme, M., Laj, P., and Delort, A.: A fate for organic acids, formaldehyde and methanol in cloud water: their biotransformation by micro-organisms, Atmos. Chem. Phys., 7, 41594169, 2007a.

Amato, P., Parazols, M., Sancelme, M., Laj, P., Mailhot, G., and Delort, A.: Microorganisms isolated from the water phase of tropospheric clouds at the Puy de Dome: major groups and growth abilities at low temperatures, FEMS Microbiol. Ecol., 59, 255264, 2007b.

Amato, P., Parazols, M., Sancelme, M., Mailhot, G., Laj, P., and Delort, A.: An important oceanic source of micro-organisms for cloud water at the Puy de Dôme (France), Atmos. Environ., 41, 8253-8263, 2007c.

Andreeva, I., Borodulin, A., Buryak, G., et al.: Biogenic Component of Atmospheric Aerosol in the South of West Siberia, Chem. Sust. Dev., 10, 523-537, 2002.

Ariya, P., Nepotchatykh, O., Ignatova, O., and Amyot, M.: Microbiological degradation of atmospheric organic compounds, Geophys. Res. Lett., 29, 2077, doi:10.1029/2002GL015637, 2002.

Ariya, P., Sun, J., Eltouny, N., Hudson, E., Hayes, C., and Kos, G.: Physical and chemical characterization of bioaerosolsImplications for nucleation processes, Int. Rev. Phys. Chem., 28, 1-32, doi:10.1080/01442350802597438, 2009.

Ariya, P. A. and Amyot, M.: New Directions: The role of bioaerosols in atmospheric chemistry and physics, Atmos. Environ., 38, 1231-1232, doi:10.1016/j.atmosenv.2003.12.006, 2004.
Arrigo, K. R. and Sullivan, C. W.: The influence of salinity and temperature covariation on the photophysiological characteristics of antarctic sea ice microalgae, J. Phycol., 28, 746-756, 1992.

Arrigo, K. R. and Thomas, D. N.: Large scale importance of sea ice biology in the Southern Ocean, Antarct. Sci., 16, 471-486, 2004.

Azam, F.: Microbial control of oceanic carbon flux: The plot thickens, Science, 280, 694-696, 1998.

Bauer, H., Kasper-Giebl, A., Löflund, M., Giebl, H., Hitzenberger, R., Zibuschka, F., and Puxbaum, H.: The contribution of bacteria and fungal spores to the organic carbon content of cloud water, precipitation and aerosols, Atmos. Res., 64, 109-119, doi:10. 1016/S0169-8095(02)00084-4, 2002.

Bauer, H., Giebl, H., Hitzenberger, R., Kasper-Giebl, A., Reischl, G., Zibuschka, F., and Puxbaum, H.: Airborne bacteria as cloud condensation nuclei, J. Geophys. Res., 108, 4658, doi:10.1029/ 2003JD003545, 2003.

Bezdek, H. F. and Carlucci, A. F.: Surface concentration of marine bacteria, Limnol. Oceanogr., 17, 566-569, 1972.

Bird, D. F. and Kalff, J.: Empirical relationships between bacterial abundance and chlorophyll concentration in fresh and marine waters, Can. J. Fish. Aquat. Sci., 41, 1015-1023, 1984.

Blanchard, D.: The ejection of drops from the sea and their enrichment with bacteria and other materials: A review, Estuaries, 12, 127-137, 1989.

Blanchard, D. and Syzdek, L.: Seven problems in bubble and jet drop researches, Limnol. Oceanogr., 23, 389-400, 1978.

Blanchard, D. and Syzdek, L.: Water-to-air transfer and enrichment of bacteria in drops from bursting bubbles, Appl. Environ. Microb., 43, 1001-1005, 1982.

Blanchard, D., Syzdek, L., and Weber, M.: Bubble scavenging of bacteria in freshwater quickly produces bacterial enrichment in airborne jet drops, Limnol. Oceanogr., 26, 961-964, 1981.

Borodulin, A., Safatov, A., Belan, B., and Panchenko, M.: Measurement errors in determining tropospheric bioaerosol concentrations in the southern region of Western Siberia, Doklady Biological Sciences, 403, 260-262, 2005a.

Borodulin, A., Safatov, A., Shabanov, A., Yarygin, A., Khutorova, O., Belan, B., and Panchenko, M.: Physical characteristics of concentration fields of tropospheric bioaerosols in the South of Western Siberia, J. Atmos. Sci., 36, 785-800, 2005b.

Bovallius, A., Bucht, B., Roffey, R., and Anäs, P.: Long-range air transmission of bacteria, Appl. Environ. Microb., 35, 1231, doi: 10.1128/AEM.01467-07, 1978a.

Bovallius, A., Bucht, B., Roffey, R., and Anas, P.: Three-year investigation of the natural airborne bacterial flora at four localities in Sweden., Appl. Environ. Microb., 35, 847-52, 1978b.

Bovallius, A., Roffey, R., and Henningson, E.: Long range transmission of bacteria, Ann. NY Acad. Sci., 353, 186-225, doi: 10.1111/j.1749-6632.1980.tb18922.x, 1980.

Bowers, R. M., Lauber, C. L., Wiedinmyer, C., Hamady, M., Halla, A. G., Fall, R., Knight, R., and Fierer, N.: Characterization of airborne microbial communities at a high-elevation site and their potential to act as atmospheric ice nuclei, Appl. Environ. Microb., 75, 5121-5130, doi:10.1128/AEM.00447-09, 2009.

Brodie, E.: Urban aerosols harbor diverse and dynamic bacterial populations, P. Natl. Acad. Sci. USA, 104, 299-304, doi: 10.1073/pnas.0608255104, 2007.

Burrows, S. M., Butler, T., Jöckel, P., Tost, H., Kerkweg, A., Pöschl, U., and Lawrence, M. G.: Bacteria in the global atmosphere: 
Part 2 - Modelling of emissions and transport between different ecosystems, Atmos. Chem. Phys., 9, 9281-9297, 2009,

http://www.atmos-chem-phys.net/9/9281/2009/.

Caristi, J., Sands, D., and Georgakopoulos, D.: Simulation of epiphytic bacterial growth under field conditions, Simulation, 56, 295-301, 1991.

Carpenter, E., Lin, S., and Capone, D.: Bacterial activity in South Pole snow, Appl. Environ. Microb., 66, 4514-4517, doi:10.1128/ AEM.66.10.4514-4517.2000, 2000.

Carrera, M., Kesavan, J., Zandomeni, R., and Sagripanti, J.: Method to determine the number of bacterial spores within aerosol particles, Aerosol Sci. Tech., 39, 960-965, 2005.

Casareto, B., Suzuki, Y., Okada, K., and Morita, M.: Biological micro-particles in rain water, Geophys. Res. Lett., 23, 173-176, 1996.

Charlson, R., Lovelock, J., Andreae, M., and Warren, S.: Oceanic phytoplankton, atmospheric sulphur, cloud albedo and climate, Nature, 326, 655-661, 1987.

Chen, M., Jin, L., Sun, Z., Lu, J., Wang, Q., Hu, Q., Sun, R., and $\mathrm{Li}, \mathrm{Z}$.: Concentration and flux of bioaerosol and environmental factors, Prog. Nat. Sci., 11, 681-687, 2001.

Chi, M.: Fluorochrome in monitoring atmospheric bioaerosols and correlations with meteorological factors and air pollutants, Aerosol Sci. Tech., 41, 672-678, 2007.

Cho, B. and Azam, F.: Biogeochemical significance of bacterial biomass in the ocean's euphotic zone., Mar. Ecol.-Prog. Ser., 63, 253-259, 1990.

Choi, D., Park, Y., Oh, S., Yoon, H., Kim, J., Seo, W., and Cha, S.: Distribution of airborne microorganisms in yellow sands of Korea, J. Microbiol., 35, 1-9, 1997.

Christner, B., Morris, C., Foreman, C., Cai, R., and Sands, D.: Ubiquity of biological ice nucleators in snowfall, Science, 319, 1214, doi:10.1126/science.1149757, 2008.

Cipriano, R.: Bubble and aerosol spectra produced by a laboratory simulation of a breaking wave, Ph.D. thesis, State University of New York at Albany, 1979.

Cole, J., Findlay, S., and Pace, M.: Bacterial production in fresh and saltwater ecosystems: A cross-system overview., Mar. Ecol.Prog. Ser., 43, 1-10, 1988.

Colwell, R.: Viable but nonculturable bacteria: a survival strategy, J. Infect. Chemo., 6, 121-125, 2000.

Constantinidou, H. A., Hirano, S. S., Baker, L. S., and Upper, C. D.: Atmospheric dispersal of ice nucleation-active bacteria: The role of rain, Phytopathology, 80, 934-937, 1990.

Courvoisier, F., Bonacina, L., Boutou, V., Guyon, L., Bonnet, C., Thuillier, B., Extermann, J., Roth, M., Rabitz, H., and Wolf, J.: Identification of biological microparticles using ultrafast depletion spectroscopy, Faraday Discuss., 137, 37-49, 2008.

Deguillaume, L., Leriche, M., Amato, P., Ariya, P. A., Delort, A.M., Pöschl, U., Chaumerliac, N., Bauer, H., Flossmann, A. I., and Morris, C. E.: Microbiology and atmospheric processes: Chemical interactions of primary biological aerosols, Biogeosciences, 5, 1073-1084, 2008,

http://www.biogeosciences.net/5/1073/2008/.

Després, V. R., Nowoisky, J. F., Klose, M., Conrad, R., Andreae, M. O., and Pöschl, U.: Characterization of primary biogenic aerosol particles in urban, rural, and high-alpine air by DNA sequence and restriction fragment analysis of ribosomal RNA genes, Biogeosciences, 4, 1127-1141, 2007, http://www.biogeosciences.net/4/1127/2007/.

di Giorgio, C., Krempff, A., Guiraud, H., Binder, P., Tiret, C., and Dumenil, G.: Atmospheric pollution by airborne microorganisms in the city of Marseilles, Atmos. Environ., 30, 155-160, 1996.

Diehl, K., Simmel, M., and Wurzler, S.: Numerical sensitivity studies on the impact of aerosol properties and drop freezing modes on the glaciation, microphysics, and dynamics of clouds, J. Geophys. Res., 111, doi:10.1029/2005JD005884, 2006.

Donaldson, A. I., Gloster, J., Harvey, L. D., and Deans, D. H.: Use of prediction models to forecast and analyse airborne spread during the foot-and-mouth disease outbreaks in Brittany, Jersey and the Isle of Wight in 1981, Vet. Rec., 110, 53-57, 1982.

Elbert, W., Taylor, P. E., Andreae, M. O., and Pöschl, U.: Contribution of fungi to primary biogenic aerosols in the atmosphere: wet and dry discharged spores, carbohydrates, and inorganic ions, Atmos. Chem. Phys., 7, 4569-4588, 2007, http://www.atmos-chem-phys.net/7/4569/2007/.

Fang, Z., Ouyang, Z., Zheng, H., Wang, X., and Hu, L.: Culturable airborne bacteria in outdoor environments in Beijing, China, Microb. Ecol., 54, 487-496, doi:10.1007/s00248-007-9216-3, 2007.

Finlay, B.: Global dispersal of free-living microbial eukaryote species, Science, 296, 1061-1063, 2002.

Francisco, D. E., Mah, R. A., and Rabin, A. C.: Acridine orangeepifluorescence technique for counting bacteria in natural waters., T. A. Microsc. Soc., 92, 416-421, 1973.

Fröhlich-Nowoisky, Pickersgill, D. A., Deprés, V. R., and Pöschl, U.: High diversity of fungi in air particulate matter, P. Natl. Acad. Sci. USA, 106, 12814-12819, doi:10.1073/pnas.0811003106, 2009.

Fulton, J.: Microorganisms of the upper atmosphere III. Relationship between altitude and micropopulation, Appl. Environ. Microb., 14, 237-240, 1966a.

Fulton, J.: Microorganisms of the upper atmosphere V. Relationship between frontal activity and the micropopulation at altitude, Appl. Environ. Microb., 14, 245-250, 1966b.

Fulton, J. and Mitchell, R.: Microorganisms of the upper atmosphere II. Microorganisms in two types of air masses at 690 meters over a city, Appl. Environ. Microb., 14, 232-236, 1966.

Gloster, J., Blackall, R., Sellers, R., and Donaldson, A.: Forecasting the airborne spread of foot-and-mouth disease., Vet. Rec., 108, 370-4, 1981.

Gloster, J., Sellers, R., and Donaldson, A.: Long distance transport of foot-and-mouth disease virus over the sea, Vet. Rec., 110, 47$52,1982$.

Gregory, P.: The Leeuwenhoek Lecture, 1970: Airborne microbes: Their significance and distribution, P. Roy. Soc. B-Biol. Sci., 177, 469-483, 1971.

Gregory, P.: The microbiology of the atmosphere, Leonard Hill, Aylesbury, UK, 1973.

Griffin, D.: Clouds of desert dust and microbiology: A mechanism of global dispersion, Microbiol. Today, 32, 180-182, 2005.

Griffin, D., Garrison, V., Herman, J., and Shinn, E.: African desert dust in the Caribbean atmosphere: Microbiology and public health, Aerobiologia, 17, 203-213, 2001a.

Griffin, D., Kellogg, C., and Shinn, E.: Dust in the wind: Long range transport of dust in the atmosphere and its implications for global public and ecosystem health, Glob. Change Human 
Health, 2, 20-33, 2001b.

Griffin, D., Kellogg, C., Garrison, V., Lisle, J., Borden, T., and Shinn, E.: Atmospheric microbiology in the northern Caribbean during African dust events, Aerobiologia, 19, 143-157, 2003.

Griffin, D., Westphal, D., and Gray, M.: Airborne microorganisms in the African desert dust corridor over the mid-Atlantic ridge, Ocean Drilling Program, Leg 209, Aerobiologia, 22, 211-226, 2006.

Griffin, D., Kubilay, N., Koçak, M., Gray, M., Borden, T., and Shinn, E.: Airborne desert dust and aeromicrobiology over the Turkish Mediterranean coastline, Atmos. Environ., 41, 40504062, 2007.

Harrison, R., Jones, A., Biggins, P., Pomeroy, N., Cox, C., Kidd, S., Hobman, J., Brown, N., and Beswick, A.: Climate factors influencing bacterial count in background air samples, Int. J. Biometeorol., 49, 167-178, 2005.

Heidelberg, J., Shahamat, M., Levin, M., Rahman, I., Stelma, G., Grim, C., and Colwell, R.: Effect of aerosolization on culturability and viability of gram-negative bacteria, Appl. Environ. Microb., 63, 3585-3588, 1997.

Herlihy, L., Galloway, J., and Mills, A.: Bacterial utilization of formic and acetic acid in rainwater, Atmos. Environ., 21, 23972402, 1987.

Hinds, W. C.: Aerosol technology: properties, behavior, and measurement of airborne particles, Wiley-Interscience, second edn., 483 pp., 1999.

Ho, J.: Future of biological aerosol detection, Anal. Chim. Acta., 457, 125-148, 2002.

Hobbie, J., Daley, R., and Jasper, S.: Use of nuclepore filters for counting bacteria by fluorescence microscopy., Appl. Environ. Microb., 33, 1225-1228, 1977.

Imshenetsky, A., Lysenko, S., and Kazakov, G.: Upper boundary of the biosphere., Appl. Environ. Microb., 35, 1-5, 1978.

Jaenicke, R.: Abundance of cellular material and proteins in the atmosphere, Science, 308, 73, doi:10.1126/science.1106335, 2005.

Jaenicke, R., Matthias-Maser, S., and Gruber, S.: Omnipresence of biological material in the atmosphere, Environ. Chem., 4, $217-$ 220, doi:10.1071/EN07021, 2007.

Jones, A. M. and Harrison, R. M.: The effects of meteorological factors on atmospheric bioaerosol concentrations - A review, Sci. Total Environ., 326, 151-180, 2004.

Junge, K. and Swanson, B.: High-resolution ice nucleation spectra of sea-ice bacteria: Implications for cloud formation and life in frozen environments, Biogeosciences, 5, 865-873, 2008, http://www.biogeosciences.net/5/865/2008/.

Junge, K., Eicken, H., and Deming, J.: Bacterial activity at -2 to $-20^{\circ} \mathrm{C}$ in Arctic wintertime sea ice, Appl. Environ. Microb., 70, 550-557, 2004.

Kellogg, C. and Griffin, D.: Aerobiology and the global transport of desert dust, Trends Ecol. Evol., 21, 638-644, 2006.

Kellogg, C., Griffin, D., Garrison, V., Peak, K., Royall, N., Smith, R., and Shinn, E.: Characterization of aerosolized bacteria and fungi from desert dust events in Mali, West Africa, Aerobiologia, 20, 99-110, 2004.

Kelly, C. and Pady, S.: Microbiological studies of air masses over Montreal during 1950 and 1951, Can. J. Botany, 32, 591-600, 1954.

Kepner, R. and Pratt, J.: Use of fluorochromes for direct enumera- tion of total bacteria in environmental samples: past and present, Microbiol. Mol. Biol. R., 58, 603-615, 1994.

Kilham, P.: Pelagic bacteria: Extreme abundances in African saline lakes, Naturwissenschaften, 68, 380-381, 1981.

Knudsen, G.: Model to predict aerial dispersal of bacteria during environmental release., Appl. Environ. Microb., 55, 2641-2647, 1989.

Kuske, C.: Current and emerging technologies for the study of bacteria in the outdoor air, Curr. Opin. Biotech., 17, 291-296, 2006.

Lee, S. and Fuhrman, J.: Relationships between biovolume and biomass of naturally derived marine bacterioplankton, Appl. Environ. Microb., 53, 1298-1303, 1987.

Lelieveld, J. and Heintzenberg, J.: Sulfate cooling effect on climate through in-cloud oxidation of anthropogenic $\mathrm{SO}_{2}$, Science, 258, 117-120, 1992.

Levin, Z. and Yankofsky, S. A.: Lecture notes in physics, atmospheric aerosols and nucleation, chap. Ice nuclei of biological origin, edited by: Wagner, P. E. and Vali, G., Springer Verlag, 620-633, 1988.

Li, W., Head, E., and Glen Harrison, W.: Macroecological limits of heterotrophic bacterial abundance in the ocean, Deep-Sea Res. I, 51, 1529-1540, 2004.

Lidwell, O.: Joseph Lister and infection from the air, Epidemiol. Infect., 99, 569-578, 1987.

Lighthart, B.: Microbial aerosols: Estimated contribution of combine harvesting to an airshed., Appl. Environ. Microb., 47, 430 432, 1984.

Lighthart, B.: The ecology of bacteria in the alfresco atmosphere, FEMS Microbiol. Ecol., 23, 263-274, 1997.

Lighthart, B.: Mini-review of the concentration variations found in the alfresco atmospheric bacterial populations, Aerobiologia, 16, 7-16, 2000.

Lighthart, B. and Kirilenko, A.: Simulation of summer-time diurnal bacterial dynamics in the atmospheric surface layer-experiments, topography, and winds, Atmos. Environ., 32, 2491-2496, 1998.

Lighthart, B. and Shaffer, B. T.: Bacterial flux from chaparral into the atmosphere in mid-summer at a high desert location, Atmos. Environ., 28, 1267-1274, 1994.

Lighthart, B., Shaffer, B., Marthi, B., and Ganio, L.: Artificial windgust liberation of microbial bioaerosols previously deposited on plants, Aerobiologia, 9, 189-196, 1993.

Lighthart, B., Shaffer, B. T., Frisch, A. S., and Paterno, D.: Meteorological variables associated with population density of culturable atmospheric bacteria at a summer site in the Mid-Willamette River Valley, Oregon, Tech. rep., U.S. Army Edgewood Chemical Biological Center, Aberdeen Proving Ground, Maryland, USA, 2004.

Lindemann, J. and Upper, C. D.: Aerial dispersal of epiphytic bacteria over bean plants, Appl. Environ. Microb., 50, 1229, 1985.

Lindemann, J., Constantinidou, H., Barchet, W., and Upper, C.: Plants as sources of airborne bacteria, including ice nucleationactive bacteria, Appl. Environ. Microb., 44, 1059-1063, 1982.

Lindow, S. and Brandl, M.: Microbiology of the phyllosphere, Appl. Environ. Microb., 69, 1875-1883, 2003.

Linley, E., Newell, R., and Lucas, M.: Quantitative relationships between phytoplankton, bacteria and heterotrophic microflagellates in shelf waters, Mar. Ecol.-Prog. Ser., 12, 77-89, 1983.

Mahdy, H. and El-Sehrawi, M.: Airborne bacteria in the atmosphere of El-Taif region, Saudi Arabia, Water Air Soil Poll., 98, 317- 
324, 1997.

Marks, R., Kruczalak, K., Jankowska, K., and Michalska, M.: Bacteria and fungi in air over the Gulf of Gdańsk and Baltic sea, J. Atmos. Sci., 32, 237-250, 2001.

Martiny, J., Bohannan, B., Brown, J., Colwell, R., Fuhrman, J., Green, J., Horner-Devine, M., Kane, M., Krumins, J., Kuske, C., et al.: Microbial biogeography: Putting microorganisms on the map, Nat. Rev. Microbiol., 4, 102-112, 2006.

Matthias-Maser, S. and Jaenicke, R.: The size distribution of primary biological aerosol particles with radii $>0.2 \mu \mathrm{m}$ in an urban / rural influenced region, Atmos. Res., 39, 279-286, 1995.

Meier, F. C.: Collecting micro-organisms from the Arctic atmosphere. With field notes and material by Charles A. Lindberg., The Scientific Monthly, 40, 5-20, 1935.

Meskhidze, N. and Nenes, A.: Phytoplankton and cloudiness in the Southern Ocean, Science, 314, 1419-1423, 2006.

Miquel, P.: Les organismes vivants de l'atmosphere, GauthierVillars, 1883.

Möhler, O., DeMott, P. J., Vali, G., and Levin, Z.: Microbiology and atmospheric processes: The role of biological particles in cloud physics, Biogeosciences, 4, 1059-1071, 2007, http://www.biogeosciences.net/4/1059/2007/.

Möhler, O., Georgakopoulos, D. G., Morris, C. E., Benz, S., Ebert, V., Hunsmann, S., Saathoff, H., Schnaiter, M., and Wagner, R.: Heterogeneous ice nucleation activity of bacteria: New laboratory experiments at simulated cloud conditions, Biogeosciences, 5, 1425-1435, 2008, http://www.biogeosciences.net/5/1425/2008/.

Monahan, E.: The Role of Air-Sea Exchange in Geochemical Cycling, chap. The ocean as a source for atmospheric particles, D. Reidel Publishing Company, 129-163, 1986.

Morris, C. and Kinkel, L.: Phyllosphere microbiology, chap. Fifty years of phyllosphere microbiology: Significant contributions to research in related fields, 365-375, APS Press, St. Paul, Minnesota, USA, 2002.

Morris, C., Georgakopoulos, D., and Sands, D.: Ice nucleation active bacteria and their potential role in precipitation, J. Phys. IV France, 121, 87-103, 2005.

Mortazavi, R., Hayes, C. T., and Ariya, P. A.: Ice nucleation activity of bacteria isolated from snow compared with organic and inorganic substrates, Environ. Chem., 5, 373-381, doi:10.1071/ EN08055, 2008.

Mouli, P., Mohan, S., and Reddy, S.: Assessment of microbial (bacteria) concentrations of ambient air at semi-arid urban region: Influence of meteorological factors., Appl. Ecol. Environ. Res., 3, 139-149, 2005.

Negrin, M., Del Panno, M., and Ronco, A.: Study of bioaerosols and site influence in the La Plata area (Argentina) using conventional and DNA (fingerprint) based methods, Aerobiologia, 23, 249-258, 2007.

Nguyen, T., Ilef, D., Jarraud, S., Rouil, L., Campese, C., Che, D., Haeghebaert, S., Ganiayre, F., Marcel, F., Etienne, J., et al.: A community-wide outbreak of Legionnaires disease linked to industrial cooling towers - how far can contaminated aerosols spread?, J. Infect. Dis., 193, 102-111, 2006.

O'Dowd, C., Langmann, B., Varghese, S., Scannell, C., Ceburnis, D., and Facchini, M.: A combined organic-inorganic sea-spray source function, Geophys. Res. Lett., 35, L01801, doi:10.1029/ 2007GL03033, 2008.
O’Dowd, C. D., Facchini, M. C., Cavalli, F., Ceburnis, D., Mircea, M., Decesari, S., Fuzzi, S., Yoon, Y. J., and Putaud, J.-P.: Biogenically driven organic contribution to marine aerosol, Nature, 431, 676-680, doi:10.1038/nature02959, 2004.

Pady, S. and Kelly, C.: Numbers of Fungi and Bacteria in Transatlantic Air, Science, 117, 607-609, 1953.

Pady, S. and Kelly, C.: Aerobiological studies of fungi and bacteria over the Atlantic Ocean, Can. J. Botany, 32, 202-212, 1954.

Pasteur, L.: Expériences relatives aux générations dites spontanées, Comptes rendus hebdomadaires des séances de l'Acad'emie des sciences, 50, 303-307, 1860a.

Pasteur, L.: Suite à une précédente communication relative aux générations dites spontanées, Comptes rendus hebdomadaires des séances de l'Acad'emie des sciences, 51, 675-678, $1860 \mathrm{~b}$.

Pastuszka, J., Kyaw Tha Paw, U., Lis, D., Wlazło, A., and Ulfig, K.: Bacterial and fungal aerosol in indoor environment in Upper Silesia, Poland, Atmos. Environ., 34, 3833-3842, 2000.

Pöschl, U.: Atmospheric Aerosols: Composition, Transformation, Climate and Health Effects, Angew. Chem. Int. Edit., 44, 7520 7540, 2005.

Pratt, K., DeMott, P., French, J., Wang, Z., Westphal, D., Heymsfield, A., Twohy, C., Prenni, A., and Prather, K.: In situ detection of biological particles in cloud ice-crystals, Nature Geosci., 2, 398-401, 2009.

Prenni, A., Petters, M., Kreidenweis, S., Heald, C., Martin, S., Artaxo, P., Garland, R., Wollny, A., and Pöschl, U.: Relative roles of biogenic emissions and Saharan dust as ice nuclei in the Amazon basin, Nature Geosci., 2, 402-405, doi:10.1038/NGEO517, 2009.

Price, P.: A habitat for psychrophiles in deep Antarctic ice, P. Natl. Acad. Sci. USA, 97, 1247, doi:10.1073/pnas.97.3.1247, 2000.

Pringle, A., Baker, D., Platt, J., Wares, J., Latge, J., and Taylor, J.: Cryptic speciation in the cosmopolitan and clonal human pathogenic fungus Aspergillus fumigatus, Evolution, 59, 18861899, 2005.

Prospero, J.: Long-term measurements of the transport of African mineral dust to the southeastern United States - Implications for regional air quality, J. Geophys. Res., 104, 15917-15927, 1999.

Prospero, J., Blades, E., Mathison, G., and Naidu, R.: Interhemispheric transport of viable fungi and bacteria from Africa to the Caribbean with soil dust, Aerobiologia, 21, 1-19, 2005.

Reyes, F., Jeys, T., Newbury, N., Primmerman, C., Rowe, G., and Sanchez, A.: Bio-aerosol fluorescence sensor, Field Anal. Chem. Tech., 3, 240-248, 1999.

Rogers, L. A. and Meier, F. C.: The collection of micro-organisms above 36,000 feet, National Geographic Society, Technical Papers, 146-151, 1936.

Rosas, I., Yela, A., and Santos-Burgoa, C.: Occurrence of airborne enteric bacteria in Mexico City, Aerobiología, 10, 39-45, 1994.

Roszak, D. and Colwell, R.: Survival strategies of bacteria in the natural environment, Microbiol. Rev., 51, 365, 1987.

Rüden, H., Thofern, E., Fischer, P., and Mihm, U.: Airborne microorganisms: Their occurrence, distribution and dependence on environmental factors - Especially on organic compounds of airpollution, Pure Appl. Geophys., 116, 335-350, 1978.

Sands, D., Langhans, V., Scharen, A., and DeSmet, G.: The association between bacteria and rain and possible resultant meteorological implications, Idojaras (Budapest), 86, 148-152, 1992.

Sattler, B., Puxbaum, H., and Psenner, R.: Bacterial growth in su- 
percooled cloud droplets, Geophys. Res. Lett., 28, 239-242, doi: 10.1029/2000GL011684, 2001.

Schlesinger, P., Mamane, Y., and Grishkan, I.: Transport of microorganisms to Israel during Saharan dust events, Aerobiologia, 22, 259-273, 2006.

Schnell, R. and Vali, G.: Atmospheric ice nuclei from decomposing vegetation, Nature, 236, 163-165, 1972.

Schnell, R. and Vali, G.: World-wide source of leaf-derived freezing nuclei, Nature, 246, 212-213, 1973.

Shaffer, B. T. and Lighthart, B.: Survey of culturable airborne bacteria at four diverse locations in Oregon: Urban, rural, forest, and coastal, Microb. Ecol., 34, 167-177, 1997.

Shahamat, M., Levin, M., Rahman, I., Grim, C., Heidelberg, J., Stelma, G., and Colwell, R.: Evaluation of media for recovery of aerosolized bacteria, Aerobiologia, 13, 219-226, 1997.

Shivaji, S., Chaturvedi, P., Suresh, K., Reddy, G., Dutt, C., Wainwright, M., Narlikar, J., and Bhargava, P.: Bacillus aerius sp. nov., Bacillus aerophilus sp. nov., Bacillus stratosphericus sp. nov. and Bacillus altitudinis sp. nov., isolated from cryogenic tubes used for collecting air samples from high altitudes, Int. J. Syst. Evol. Micr., 56, 1465, doi:10.1099/ijs.0.64029-0, 2006.

Sørensen, J. H., Mackay, D. K. J., Jensen, C., and Donaldson, A. I.: An integrated model to predict the atmospheric spread of foot-and-mouth disease virus, Epidemiol. Infect., 124, 577-590, 2000 .

Spracklen, D., Arnold, S., Sciare, J., Carslaw, K., and Pio, C.: Globally significant oceanic source of organic carbon aerosol, Geophys. Res. Lett., 35, L12 811, doi:10.1029/2008GL033359, 2008.

Staley, J. and Konopka, A.: Measurement of in situ activities of nonphotosynthetic microorganisms in aquatic and terrestrial habitats, Annu. Rev. Microbiol., 39, 321-346, 1985.

Stewart, S., Grinshpun, S., Willeke, K., Terzieva, S., Ulevicius, V., and Donnelly, J.: Effect of impact stress on microbial recovery on an agar surface., Appl. Environ. Microb., 61, 1232-1239, 1995.

Sun, J. and Ariya, P. A.: Atmospheric organic and bio-aerosols as cloud condensation nuclei $(\mathrm{CCN})$ : A review, Atmos. Environ., 40, 795-820, doi:10.1016/j.atmosenv.2005.05.052, 2006.

Sussman, A. and Halvorson, H.: Spores, their dormancy and germination, Harper \& Row New York, 1966.

Tilley, R., Eamus, D., and Ho, J.: Background bioaerosols and aerosols at two sites in northern Australia: Preliminary measurements, Tech. rep., DSTO Aeronautical and Maritime Research Laboratory, Victoria, Australia, 2001.

Timmons, D., Fulton, J., and Mitchell, R.: Microorganisms of the upper atmosphere I. Instrumentation for isokinetic air sampling at altitude, Appl. Environ. Microb., 14, 229-231, 1966.

Tong, Y. and Lighthart, B.: Diurnal distribution of total and culturable atmospheric bacteria at a rural site, Aerosol Sci. Tech., 30, 246-254, 1999.
Tong, Y. and Lighthart, B.: The annual bacterial particle concentration and size distribution in the ambient atmosphere in a rural area of the Willamette Valley, Oregon, Aerosol Sci. Tech., 32, 393-403, doi:10.1080/027868200303533, 2000.

Vlodavets, V. and Mats, L.: The influence of meteorological factors on the microflora of the atmospheric air in Moscow, J. Microbiol., 59, 539-544, 1958.

Wagner, M., Smidt, H., Loy, A., and Zhou, J.: Unravelling microbial communities with DNA-microarrays: Challenges and future directions, Microb. Ecol., 53, 498-506, 2007.

Wainwright, M., Wickramasinghe, N., Narlikar, J., and Rajaratnam, P.: Microorganisms cultured from stratospheric air samples obtained at $41 \mathrm{~km}$, FEMS Microbiol. Lett., 218, 161-165, doi: 10.1111/j.1574-6968.2003.tb11513.x, 2003.

Wainwright, M., Wickramasinghe, N. C., Narlikar, J. V., Rajaratnam, P., and Perkins, J.: Confirmation of the presence of viable but non-cultureable bacteria in the stratosphere, Int. J. Astrobiology, 3, 13-15, 2004.

Wang, C.-C., Fang, G.-C., and Lee, L.-Y.: Bioaerosols study in central Taiwan during summer season, Toxicol. Ind. Health, 23, 133-139, doi:10.1177/0748233707078741, 2007.

Wang, C.-C., Fang, G.-C., and Lee, L.-Y.: The study of ambient air bioaerosols during summer daytime and nighttime periods in Taichung, Central Taiwan, Environ. Forensics, 9, 6-14, doi:10. 1080/15275920701729175, 2008.

Wang, Z., Reponen, T., Grinshpun, S. A., Górny, R. L., and Willeke, K.: Effect of sampling time and air humidity on the bioefficiency of filter samplers for bioaerosol collection, J. Aerosol Sci., 32, 661-674, 2001.

Whitman, W., Coleman, D., and Wiebe, W.: Prokaryotes: The unseen majority, P. Natl. Acad. Sci. USA, 95, 6578-6583, 1998.

Williams, P. J.: Incorporation of microheterotrophic processes into the classical paradigm of the planktonic food web, Kiel. Meeresforsch. Sonderh., 5, 1-28, 1981.

Wolfenbarger, D. O.: Dispersion of small organisms. Distance dispersion rates of bacteria, spores, seeds, pollen, and insects; Incidence rates of diseases and injuries, Am. Midl. Nat., 35, 1-152, 1946.

Yankofsky, S. A., Levin, Z., Bertold, T., and Sandlerman, N.: Some basic characteristics of bacterial freezing nuclei, Journal of Applied Meteorology, 20, 1013-1019, 1981a.

Yankofsky, S. A., Levin, Z., and Moshe, A.: Association with citrus of ice nucleating bacteria and their possible role as causative agents of frost damage, Current Microbiology, 5, 213-217, 1981b.

Yousefi, V. and Rama, D.: Monitoring of air for microbial and metal contamination at selected sites in the vicinity of Johannesburg, South Africa., Sci. Total Environ., 116, 159-167, 1992.

ZoBell, C. and Mathews, H.: A qualitative study of the bacterial flora of sea and land breezes, P. Natl. Acad. Sci. USA, 22, 567$572,1936$. 